UDC 65.012.6

JEL Classification: 012, D22

http://doi.org/10.21272/mmi.2019.2-23

Tomasz Rojek,

Ph.D., Cracow University of Economics, Poland

\title{
ANALYSIS OF PRO-MARKET CONCEPT OF BUSINESS MODEL
}

Abstract. Contemporary concepts of business models are mainly oriented towards realizing the maximum development of enterprises. The development translates directly into resource growth, competitiveness, and profitability. The business model of an enterprise is conditioned by internal factors understood as possibilities for growth and management efficiency on the one hand and by external factors based first of all on the cooperation among enterprises and other entities of the environment and the efficiency of the institutional infrastructure stimulating the development of enterprises on the other. Simultaneously, this is realized in accordance with the adopted strategies of development that, in turn, are mainly conditioned by the directions of development adopted by the enterprise, which play the roles of a determinant and modifier of a decision-making process within the scope of defining the possibilities as well as the choice of the adequate development strategy. Product-oriented development and market-oriented development are the directions of development that most frequently appear in the literature on the subject. The examples of successful enterprises show that development is possible to achieve via these two exact ways. Therefore, two concepts of business models currently stand out: the pro-market concept and the proproduct concept. This paper presents the problems concerning the market-oriented development of enterprises, a pro-market concept of a business model, and the resulting development strategies. The empirical part presents the research carried out among a selected group of stock-listed companies during the period of 2010-2018, consisting of the frequency analysis of this business model concept occurrence. The purpose of the paper is to present contemporary concepts of business models focused on business development and developmental strategies that enterprises implement and the frequency analysis of the pro-market concept of a business model on the Polish market. The implementation of the paper objective allowed for the verification of the following research hypothesis: "the pro-market concept of a business model is a leading concept among Polish enterprises». In the theoretical part of the paper, a review and critical analysis of the literature related to the proposed topic was made, while in the empirical part, the strategic analysis of the companies was used (the Ansoff Model in particular) based on the matrix of development vectors. This model has been transformed and modified in terms of the aim of the conducted research. The application of this model enabled the identification of enterprises using the analyzed concept of the business model in the group of researched enterprises and the development strategies applied in these enterprises. This research is designed to facilitate the decision of Polish entrepreneurs in the selection of the right business model and an indication of the resulting consequences.

Keywords: business development, business model, developmental strategies, enterprise development, the promarket concept of a business model, strategic management.

Introduction. The contemporary economy and the changes undergoing within it are posing new challenges to enterprises. They are often related to the constantly growing influence of globalization and integration processes on the possibilities of functioning and developing economic entities. At present, these processes constitute new civilization mega-trends that are shaping social and economic reality to a greater and greater degree. Globalization mainly has its source in the progressing economic, political, and social integration as well as in the development of an information infrastructure that enables the fast flow of information and the extension of access to it. Therefore, globalization is related to the supranational perspective of perceiving economic, social, and political processes (Buckley and Tian, 2017). In this context, competition among enterprises is constantly increasing, which has resulted in the dynamics of changes that were difficult to imagine until recently. Today, the turbulent and fast-changing surroundings create a natural environment in which practically all economic entities have to conduct their activity. This is why the identification and choice of an appropriate business model for a given entity are currently becoming more and more important; one that offers a real description of the activities of a

Cite as: Rojek, T. (2019). Analysis of Pro-Market Concept of Business Model. Marketing and Management of Innovations, 2, 266-281. http://doi.org/10.21272/mmi.2019.2-23 
business, ensuring it adequate efficiency. This boils down to defining the role of an enterprise in the value chain in which it operates. Comprehensively, it is about a method adopted by an enterprise through the implementation of which will help it increase and use resources in such a way that it could offer greater value than its competitors. Owing to that, the enterprise will achieve higher efficiency and, consequently, will achieve and maintain a permanent competitive advantage (Baden-Fuller and Mangematin, 2013).

The globalization processes and the huge dynamics of the enterprise environment influence the permanent reorientation of the hitherto prevailing imperatives of their functioning as well as the transformation of the whole system of enterprise management (as well as the individual functional subsystems within its scope). Thus, the contemporary practice of conducting economic activity requires the possession of the skill of adapting tasks and functions as well as the organization of work and management methods to constantly adapt to the changing conditions of the environment (Pelikanova and McGregor, 2019). Under these conditions, the survival of an enterprise and guaranteeing an opportunity to realize the assumed goals towards it require the introduction of radical changes in the systems of management, the technology of production and service provision, modernization, and offering new products (Cygler and Wyka, 2019). In this aspect, enterprise management is a multi-faceted and complex process that is characterized by a variety of business models and, as a consequence, also by forms and trends as well as mutually correlated and complementing techniques, systems, and best practices. This fact causes the high dynamics of the evolution of the concepts of business models as well as the constant formation and shaping of new views and paradigms in the area of management. Afuah and Tucci claim that a business model is a method that is adopted by an organization for increasing and using their resources in order to present the offer of products and services to customers, the value of which exceeds the competitors' offers and at the same time ensures profitability for the firm. Such a model defines a detailed plan for earning money (both currently and in the long term) as well as factors conditioning the maintenance of permanent competitive advantage by the business. This means the achievement (in the long term) of better results than their competitors (Afuah et al., 2003).

In the context of the conditioning of the contemporary enterprises' functioning understood in this way, the changeability and interactivity of business processes, the development of technique and technology, the turbulence of the environment in which the enterprises function, and the instability of the market are the main factors that stimulate managers to search for proper strategies of activity and create such adoptive solutions to the market conditions that will enable the entities managed by them to simultaneously link the efficiency and effectiveness of the ongoing activity and achieve success in the future. The afore-mentioned reorientation of the enterprises' functioning strategy undergoing under the influence of the current internal and external conditioning would not be possible without making transformations in the area of the hierarchization of the enterprise goals and the consequences resulting from it. It should be observed here that, regardless of any new challenges, contemporary enterprises cannot forget about the classic and (at the same time) invariably valid goals and rules of functioning. The thesis determines the fact that, in spite of the new aforementioned changes and new conditioning in the sphere of conducting economic activity, the survival and development are still regarded as the basic and superior aim of the functioning of an organization. As a rule, the aim of survival dominates under the conditions of instability in an economic system, recession, and the lack of competition, whereas development as the guidance aim is realized under the conditions of economic growth and the pressure of competition and market forces. The need for these results from the natural internal endeavours of each enterprise. This thesis is the basis for contemporary concepts of business models of enterprises that consist in the shaping of economic, organizational, personal, information and technical, and manufacturing progress, which in effect is supposed to bring about the prolongation of periods of positive changes as well as the shortening or elimination of periods of negative changes and, consequently, the 
growth of an enterprise measured with the efficiency of its functioning (Johnson, Christensen, Kagermann, 2008). Treated as the quantitative manifestation of its development, an enterprise's growth is, in turn, most frequently the one condition that is necessary for its survival. As a rule, enterprise development understood in this way brings about a rise in the market share and growth in competitiveness under the conditions of the market economy. An enterprise that does not enlarge the scale of activity together with the growth of the market decreases its market share and loses the ability for further development at the same time. Therefore, development is nowadays treated as a necessary determinant of the functioning of economic entities in the market economy, at the same time contributing to the growth of enterprise value, which is achieved thanks to the more effective use of its economic resources.

Literature Review. The notion of development has a broad conceptual scope. In scientific literature, development is understood as the process of transformations and changes evolving to more complex or, in some ways, more perfect states and forms. In a broader context, development is the process of transforming economic, social, political, and mental structures that cannot be made in a short period of time. Enterprise development is a dual category. On the one hand, it is conditioned by internal factors the possibilities of growth and efficiency of management - and on the other hand by external factors cooperation among enterprises and other entities from the environment and the efficiency of institutional infrastructure that stimulates the development of entrepreneurship (e.g., the facilitation of administrative issues, court procedures, procedures connected with the registration of entities, or the issuance of permits for conducting business activity). Development is a process that occurs when the growth of an enterprise is justified by the efficiency of its management processes. The growth of an enterprise is a permanent increase in its size measured with a set measure as a result of maintaining positive changes in the efficiency of the conducted processes of enterprise management. On the other hand, management efficiency is a feature of the processes coordinating the functioning of an enterprise in which the managers make decisions concerning the resources and skills possessed by the enterprise in accordance with the needs of the set goals, functions, and tasks as well as with the consideration of their cost rationality.

In the contemporary approach to development, the pressure is first of all put on a certain way of thinking and not specific techniques or methods (Doligalski, 2018). Successfully realized developmental ventures are characterized by comprehensiveness and many-sidedness. Therefore, strategic thinking is considered to be a necessary element of the efficient development of an organization in a contemporary enterprise's functioning in a turbulent environment, as it introduces planning and rationality to it. This fact has a purely pragmatic basis because, in strategic thinking, originality has much less important than the ability to synthesize what has already been achieved, distinctly indicating areas in which the application of a strategy may bear the most fruit, emphasizing the necessity to make choices among various strategies, and locating each strategy individually for a specific enterprise and its environment. However, we should remember that there is no one universal strategy that may be applied in each situation. An approach to forecasting future changes proportionally; this is related to the appearing problems and changing requirements of the market. A turbulent environment (dynamically changeable and complex) requires the use of various tools by enterprises in order to plan for the future and support the formulation of the proper directions and strategies of development. The strategies of enterprise development are worked out mainly to show the possibility of the comprehensive holistic development of an enterprise. While choosing certain strategies, organizations try to maximize opportunities and abilities while minimizing threats and weaknesses. The strategy is generally understood as a plan that includes tasks referring to the functioning of an organization in the future. Strategy constitutes an overall economic strategy that presents the dominating direction of a given entity's activity. In this understanding, the strategy is the main plane and the azimuth of an enterprise manager's actions due to the changes that 
occur in the environment and when assessing the enterprise's competitive potential (human, organizational, financial, technical, and production capital). The strategy is a system of certain values by means of which an enterprise recognizes and assesses emerging chances and threats according to which it selects and undertakes specific actions that aim at ensuring a long-term existence to it.

Nowadays, the strategies of enterprises (and strategies of development in particular) are closely connected with business models in spite of the fact that we can also often come across the opinion that business models have now replaced the strategies of enterprise operations. It is difficult to agree with the thesis formulated in this way. Actually, a business model is expected not only to determine the operations leading to the growth of enterprise value but also to define the method of their implementation, which includes designing the organization and the system of managing it. Thus, it is a multi-threaded issue that provides enterprises with the opportunities for strategic choice to shape their strategic position, build a strategy, and implement changes in the enterprises. A business model presents arguments that justify the application of a selected strategy of creating value by an enterprise and the provision and absorption of profits coming from this value (Arend, 2013). Thus, they are complementary notions. It has been proven by A.A. Thompson and A.J. Strickland, who believe that the business model of an enterprise refers to the revenue-cost-profit relationship within the enterprise strategy and concerns actual and predictable streams of revenues, achieved owing to the competitiveness of the enterprise's offer, the relative structure of costs and margins, and the resulting streams of income and return on investment (Thompson, Strickland 2003). A similar view is also presented by H. Chesbrough and R.S. Rosenbloom. In their understanding, a necessary component of a business model is the formulation of a strategy of competing, ensuring the achievement and maintenance of advantage on the market (Chesbrough, Rosenbloom, 2002).

Within this research, an extensive literature review was carried out (Geissdoerfer at al., 2018; Zott, Amit, 2010; Smith, Binns, Tushman, 2010; DaSilva, Trkman, 2014) during which it was established that there are a number of definitions and classifications of business models among which there are an unclear terminology difference and implementation potential. Moreover, we can find more and more new concepts of business models in economic practice that have not been described in the literature so far (or their description is not full). The lack of adequate sources of information about all contemporary enterprise business models with their practical verification makes it difficult for scientists and practicians to interpret them properly and implement them in economic entities. This potentially limits research, education, and training within that scope and constitutes a significant barrier to the implementation and adaptation of proper business models in enterprises. Moreover, it is also an obstacle to achieving a possible synergy effect between an appropriate business model, the currently conducted activity, and the conditioning of the environment. The practice of conducting economic activity shows that such a synergy effect is nowadays one of the basic factors for maximizing the efficiency of business entities' operations. Therefore, two new concepts of business models really adopted by enterprises on the studied market were identified in the course of the conducted research; their influence on the development of the studied entities was assessed, focusing particularly on the pro-market concept.

The aim of the paper is to present contemporary concepts of business models oriented at an enterprise's development and the strategy of development each implements as well as to analyze the frequency of the occurrence of the pro-market concept of the business model on the Polish market. The realization of the aim of the paper made it possible to verify the research hypothesis; namely, the promarket concept of a business model is a leading concept among Polish enterprises.

In the verification of the hypothesis thus formulated, a review and critical analysis of the literature related to the proposed subject was made, while an enterprise strategic analysis was applied in the empirical part, especially the Ansoff's model (transformed and adapted by the author in terms of the conducted research), based on the matrix of development vectors. The application of this model enabled 
the identification of enterprises using the analyzed concept of the business model in the group of the studied enterprises as well as the strategies of development used in those enterprises. The research aims at the facilitation of making a decision by Polish entrepreneurs as for the choice of the proper business model and indicating the consequences resulting from it. At the same time, it is worth mentioning that the research carried out is pioneering on the Polish market.

Methodology and research methods. Within the attempt made to solve the research gap presented above, various methodological techniques were applied in accordance with the recommendations (Creswell, 2014). First, a review of the literature and the author's own experiences was made, and then broad consultations and discussions were conducted with representatives of company managers. Finally, the selected research model was used; by means of this, the research was carried out on a selected group of enterprises. The aim of the research was to identify and present contemporary actually used concepts of business models focused on enterprise development, the strategies of development arising from them, and then the frequency of the occurrence of the pro-market concepts of the business model on the Polish market in the selected sectors of the economy that were assessed. In the contemporary economy, the necessity to search for strategies whose aim is to indicate (identify) new sources of competitive advantages that would enable them to react to changes in the global environment seems to be a paradigm that determines the direction of the activity of enterprises.

Enterprise development strategies are primarily conditioned by the adopted concepts of business models, which perform the function of a determinant and modifier of the decision-making process in defining the opportunities as well as the choice of a proper strategy of development (Richardson, 2008; Casadesus-Masanell and Ricart, 2010). For the needs of the conducted research, the basis for discussing these problems will be H.I. Ansoff's model showing the possibilities of choosing a proper business model of an enterprise as well as the relationships between enterprise business models and the choice of an appropriate strategy of development (Ansoff, 1957). Developed at the end of the 1950s, this model includes a set of strategies for development in the form of vectors included in the productmarket matrix. This model has been transformed and modified in terms of the aim of the conducted research. H.I. Ansoff's model is presented in Figure 1.

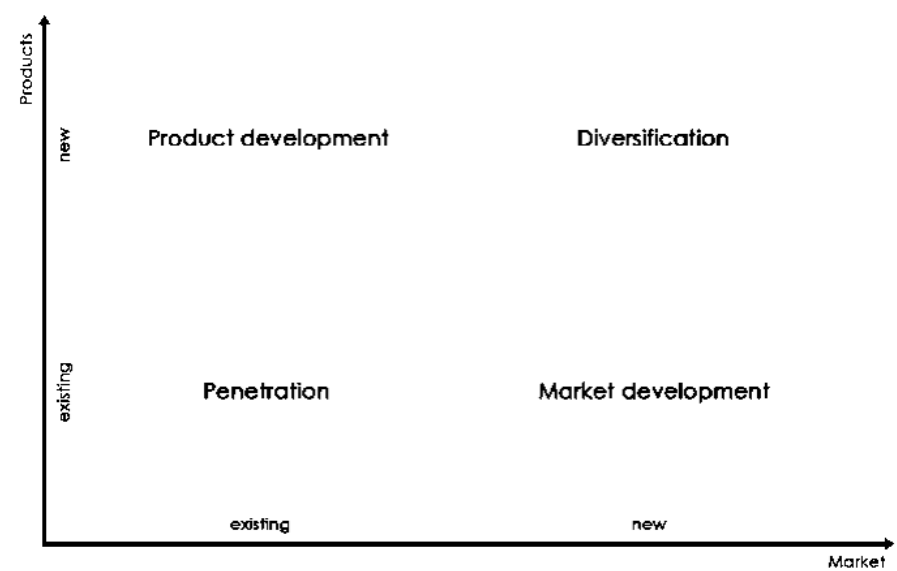

Figure 1. H.I. Ansoff's model of the strategy of development

Source: Ansoff (1965, p. 109); Boyd et al. (1995, p. 35).

In the transformed Ansoff's model (modified for the needs of the conducted research), enterprise development can be realized within two business models: 
1. Product-oriented development (pro-product business model) - enterprises implementing this business model extend or modify the variety of goods and services produced within one sector as well as launch activity in new sectors and industries;

2. Market-oriented development (pro-market business model) - enterprises implementing this business model extend sales to new groups of customers or new geographical areas.

The choice of a proper strategy of development consists of selecting a specific scope of the applied business model (product-oriented development and market-oriented development); that is, finding a point in the presented matrix that would be optimum for a given organization. There are four possible model strategies for development:

- market penetration strategy - consists of undertaking actions that aim at increasing an enterprise's product sales in the existing market by encouraging customers to increase the number and frequency of purchases or searching for new customers;

- product development strategy - consists of investing in products and introducing modifications of a product and product innovations and (most of all) extending the product range and entering new sectors and industries;

- market development strategy - consists of offering the existing products in geographically new markets or to segments of customers thus far untapped;

- diversification strategy - consists of entering a new market with new products.

The modified Ansoff model points to an alternative character of individual concepts of enterprise business models. It may be used as a helpful tool in establishing the best development strategy for the enterprise, and it may be a basis to define the current enterprise strategy or its changes over time. Using Ansoff's model, it is possible to:

- define and mark the enterprise's current strategy on a chosen square of the matrix,

- show the evolution of the strategy of the development of a given enterprise in the long-term, marking consecutive years on the matrix,

- show the diversity of the strategy of development in the studied population of enterprises.

In the literature, we can also come to cross numerous other strategies of enterprise development (Zapletalova, 2017), however, they are often an extension, variation, or complement of strategies based on Ansoff's model. Ansoff is considered to be one of the pioneers creating the bases of strategic management, and his model seems to be one of the first fully formed concepts of strategic management as a systemized complete set of enterprise development strategies. A significant advantage of Ansoff's model is the possibility of its adjustment and modification in terms of the needs of specific research. Therefore, while conducting the research referring to the market-oriented development of the selected enterprises, the subjective model was used as a benchmark for the proper assessment.

Results. Taking into consideration the fact that the contemporarily existing tendencies of enterprise management most often consist of the maximization of its owners' benefits, within the framework of the conducted research, companies listed on the Warsaw Stock Exchange (WSE) were adopted as the object. As a rule, these are enterprises with a long history of activity, advanced in the application of modern solutions in the management sphere, strongly related to the capital market and interested in the growth of their shareholders' benefits. At the same time, the stock exchange division into sectors guarantees the possibility of studying isolated groups that are homogenous as far as the adopted criteria are concerned. The Warsaw Stock Exchange is a public institution whose goal is to ensure the trading of securities (such as shares, bonds, pre-emptive rights, etc.) admitted to the listing. The WSE task is to organize the trading of financial instruments. The stock exchange ensures the concentration of sellers' and buyers' offers in one place and at one time in order to determine the index and conclusion of transactions. The Warsaw Stock Exchange is one of the most dynamic European markets, and it is an unquestionable leader in Central and Eastern Europe in respect of the key indices describing the market 
development level such as capitalization, the turnover value, and the number of new companies entering the stock market. In terms of the number of listings, the Warsaw Stock Exchange has been at the forefront of European stock exchanges for several years. Such a dynamic and spectacular growth of the Warsaw Stock Exchange has made it attractive to investors, issuers, and firms mediating in trading from many countries of the world; today, the Warsaw Stock Exchange is a fully international market. Since the beginning of the existence of the stock exchange, shares have been most popular among individual investors; therefore, Table 1 presents the basic data concerning the companies listed on the WSE during the years of 2010-2018.

Table 1. Data concerning companies listed on WSE during years of 2010-2018

\begin{tabular}{|c|c|c|c|c|c|c|c|c|c|c|}
\hline No & Specification & 2010 & 2011 & 2012 & 2013 & 2014 & 2015 & 2016 & 2017 & 2018 \\
\hline \multirow{3}{*}{1} & $\begin{array}{c}\text { Number of listed } \\
\text { companies at the end of } \\
\text { the year }\end{array}$ & 400 & 426 & 438 & 450 & 471 & 487 & 487 & 482 & 465 \\
\hline & $\begin{array}{l}\text { - out of which are } \\
\text { domestic companies }\end{array}$ & 373 & 387 & 395 & 403 & 420 & 433 & 434 & 432 & 414 \\
\hline & $\begin{array}{c}\text { out of which are foreign } \\
\text { companies }\end{array}$ & 27 & 39 & 43 & 47 & 51 & 54 & 53 & 50 & 51 \\
\hline \multirow{3}{*}{2} & \begin{tabular}{|c|} 
Capitalization of \\
companies (in millions \\
PLN) \\
\end{tabular} & 796,482 & 642,863 & 734,048 & 840,780 & $\begin{array}{c}1,252,95 \\
8\end{array}$ & $\begin{array}{c}1,082,86 \\
3\end{array}$ & $\begin{array}{c}1,115,71 \\
9\end{array}$ & $\begin{array}{c}1,379,85 \\
8\end{array}$ & $\begin{array}{c}1,128,50 \\
8\end{array}$ \\
\hline & \begin{tabular}{|c|} 
- out of which are \\
domestic companies
\end{tabular} & 542,646 & 446,151 & 523,390 & 593,464 & 591,165 & 516,785 & 557,124 & 670,976 & 578,949 \\
\hline & $\begin{array}{c}\text { - out of which are foreign } \\
\text { companies }\end{array}$ & 253,836 & 196,712 & 210,657 & 247,316 & 661,793 & 566,077 & 558,596 & 708,882 & 549,558 \\
\hline 3 & Average P/E ratio & 18.2 & 12.5 & 11.7 & 15.8 & 29.9 & 18.3 & 17.3 & 39.2 & 11.8 \\
\hline 4 & Average P/BV ratio & 1.16 & 1.06 & 0.89 & 0.96 & 1.09 & 1.05 & 0.82 & 1.09 & 0.87 \\
\hline 5 & Dividend yield (\%) & 2.4 & 2.9 & 3.9 & 3.6 & 3.1 & 2.3 & 3.4 & 2.3 & 3.3 \\
\hline 6 & $\begin{array}{c}\text { Value of turnover in the } \\
\text { whole year (in millions } \\
\text { PLN) }\end{array}$ & 234,288 & 268,138 & 202,880 & 256,146 & 232,865 & 225,287 & 202,293 & 260,978 & 211,850 \\
\hline
\end{tabular}

Source: developed by the author on the basis of WSE data.

In the process of selecting the research objects, the sector approach was used; this consists of choosing the research enterprises grouped in sectors as related to the criterion of the subject of activity. The chosen (or all) participants of the sector are placed against the sector, and the relationships and reactions among them are described. This approach assumes that an enterprise's activities are a reaction to the undergoing changes in the sector and (first of all) to the decisions made by the most important competitors. The approach does not require going into the decision-making mechanism. An enterprise is treated as an object that transforms information and supplies inputs into certain decisions. Their big susceptibility to development (adopted by assumption, ex-ante) should be a criterion of selecting sectors for the research. A lot of reasons (especially practical ones) speak for choosing the sector approach for the research into the strategic behaviour of the enterprises. The following reasons lead to the decision.

Due to the reluctance of enterprises to give interviews and reveal data and information, it seems more real to observe enterprises from the outside and record their strategic reactions.

The sector approach enables us to better understand the logic of enterprise behaviour, since it relates them to changes undergoing in the whole economy, the sector, and in the behaviour of the sector participants, eliminating subjective ways of explaining the behaviour of enterprises. The sector research 
is less laborious and cheaper - as a result, it can include a greater area of the economy and number of enterprises, which then translates into a broader base for formulating generalizations. In accordance with the methodological assumptions, the research includes enterprises grouped in five WSE sectors: construction, electromechanical, IT, metallurgical, and food. It was assumed ex-ante that all sectors selected for the research are sectors that are to a great extent susceptible to development, adequately numerous, and grouping enterprises with a long presence on the WSE.

Due to the necessity to establish the period and number of the studied enterprises (being a compromise between the requirement to obtain a large enough number of the studied group and conduct an analysis in a long enough period), the following arrangements were made:

1. The years of $2010-2018$ were adopted as the period of analysis;

2. The total number of 66 enterprises (companies) were chosen as the object of the research, and each of them was listed on the WSE from 2010 until the end of 2018 at the latest.

Table 2 shows the presentation of the studied enterprises with a division into sectors.

Table 2. Presentation of all sector enterprises

\begin{tabular}{|c|c|c|c|c|}
\hline \multicolumn{5}{|c|}{ Sectors } \\
\hline Construction & Electromechanical & IT & Metallurgical & Food \\
\hline BUDIMEX & AMICA & ASSECOPOL & ALCHEMIA & AMBRA \\
\hline DECORA & APATOR & COMARCH & BORYSZEW & GOBARTO \\
\hline ELBUDOWA & HYDROTOR & ELZAB & COGNOR & INDYKPOL \\
\hline ELKOP & INTROL & IFIRMA & FASING & KERNEL \\
\hline ENAP & LENA & OPTEAM & FERRUM & KSGAGRO \\
\hline ERBUD & MANGATA & PROCAD & HUTMEN & KRUSZWICA \\
\hline ES-SYSTEM & PATENTUS & SIMPLE & IMPEXMET & MILKILAND \\
\hline FERRO & RAFAKO & SYGNITY & KETY & PEPEES \\
\hline HERKULES & RELPOL & TALEX & KGHM & WAWEL \\
\hline INSTALKRK & REMAK & WASKO & MENNICA & ZYWIEC \\
\hline LENTEX & WIELTON & & ODLEWNIE & \\
\hline MOSTALPLC & ZPUE & & PERMEDIA & \\
\hline MOSTALWAR & & & STALPROD & \\
\hline MOSTALZAB & & & & \\
\hline PBG & & & & \\
\hline PEMUG & & & & \\
\hline POLIMEXMS & & & & \\
\hline PROCHEM & & & & \\
\hline PROJPRZEM & & & & \\
\hline SELENA & & & & \\
\hline ULMA & & & & \\
\hline SOUTCE: & & & \\
\hline
\end{tabular}

Source: developed by the author on the basis of WSE data and websites of studied enterprises.

The construction sector is a sector that concentrated the largest number of companies on the Warsaw trading floor at the end of 2018. It is also regarded as one of the most profitable and prospective sectors. The electromechanical industry stands out with increased diversification of produced goods and a high ranking in the economy. At present, it is the most dynamically developing sector in highly developed countries. Its role consists of supplying machines and devices for other branches of industry and economy. The development level of this sector influences the overall level of production as well as the quality of goods. Thus, the relationships between the electromechanical sector and the fields of science are important, as is its ability to turn fast technological achievements into the production 
process. It requires the extensive involvement of capital, high-tech engineering solutions, and highly qualified employees. The IT sector is a sector that has very high dynamics and the expected beneficial prospects of development. At present, the number of companies comprises this group, but the majority of them are characterized by less seniority on the stock exchange.

The metallurgical sector group enterprises deal with the production and processing of metals and related products, the extraction of metallic ores, and foundry processes as well as the production of fixtures, tinware, tools, and vessels. The production of metal finished goods shows the highest growth dynamics in this sector, whereas the production of metals shows the lowest dynamics. The prospects for the development of the metallurgical sector in Poland are considered to be favourable, so an increase in the investment expenditure in this sector is planned. This will accompany the modernization and development of the Polish economy. The food sector is one of the most important and fastest-growing branches of the economy in Poland. Globalization processes and the gradual abolishment of international trade barriers accompanying them have increased the role of competitive struggles among enterprises in the internal and external markets. The conditionings have positively influenced Polish food sector enterprises that, in addition to taking advantage of European Union support for this program, have coped with competition and market forces and become a significant element of competition in the European and world markets. Enterprises of the Polish food sector are now strongly connected to the international market and capital, which have also recognized it as a prospective sector whose development is worthy of investment. The pro-market business model operates to the benefit of one of the two most important directions of enterprise development according to Ansoff's model. It consists of extending the territory of the sales of an enterprise's goods and services; namely, in entering new geographical areas (markets). Thus, the degree of the realization of the pro-market business model in the studied enterprises was analyzed within the conducted research. For the needs of the conducted assessment, the following assumptions and denotations were adopted:

1. A - means an enterprise with a local reach; namely, one conducting sales of its products and services in areas ranging from a commune to a province.

2. B - means an enterprise with a national reach; namely, one conducting sales of its products and services in areas ranging from regional (in more than one province) to national.

3. C - means an enterprise with a multinational reach; namely, one conducting sales of its products and services abroad - in not more than 20 countries.

4. D - means an enterprise with a multinational reach; namely, one conducting sales of its products and services in more than 20 countries worldwide.

The classification of the surveyed enterprises to specific groups was made based on the annual financial reports from 2010-2018, Annals of the WSE, annual reports of the management boards of the surveyed enterprises, and information posted online. The results of the research conducted in this scope are presented in Tables 3-7. The data included in Table 3 inclines to a thesis that the construction sector enterprises are characterized by increased activity within the scope of their market-oriented development. As many as 12 companies extended their geographical markets of activity during the analysed period; these were BUDIMEX, DECORA, ELBUDOWA, ERBUD, ES-SYSTEM, INSTALKRK, LENTEX, MOSTALWAR, PBG, PROCHEM, PROJPRZEM, and ULMA. At the same time, none of the companies of this sector limited their market, and four companies marked no changes in the discussed area (ELKOP, FERRO, HERKULES, and PEMUG). Five companies of the sector were characterized by fluctuations consisting of expanding and limiting their geographical markets: namely, ENAP, MOSTALPLC, MOSTALZAB, POLIMEXMS, and SELENA.

Contrary to the construction sector, the electromechanical sector companies are characterized by low activity in the area of extending their geographical markets of activities. As can be seen in Table 4, as many as nine companies of this sector (AMICA, HYDROTOR, LENA, PONAR, RAFAKO, RELPOL, 
REMAK, WIELTON, and ZPUE) marked no significant changes in this scope in the studied period. At the same time, three companies extended their geographical markets (APATOR, INTROL, and MANGATA), yet none limited it.

Table 3. Overview of the degree of market-oriented development realized in construction sector companies during years of 2010-2018

\begin{tabular}{|c|c|c|c|c|c|c|c|c|c|c|}
\hline No. & Company & $\mathbf{2 0 1 0}$ & $\mathbf{2 0 1 1}$ & $\mathbf{2 0 1 2}$ & $\mathbf{2 0 1 3}$ & $\mathbf{2 0 1 4}$ & $\mathbf{2 0 1 5}$ & $\mathbf{2 0 1 6}$ & $\mathbf{2 0 1 7}$ & $\mathbf{2 0 1 8}$ \\
\hline 1 & $\mathrm{BUDIMEX}$ & $\mathrm{B}$ & $\mathrm{B}$ & $\mathrm{B}$ & $\mathrm{C}$ & $\mathrm{C}$ & $\mathrm{C}$ & $\mathrm{C}$ & $\mathrm{C}$ & $\mathrm{C}$ \\
\hline 2 & $\mathrm{DECORA}$ & $\mathrm{A}$ & $\mathrm{A}$ & $\mathrm{A}$ & $\mathrm{A}$ & $\mathrm{A}$ & $\mathrm{A}$ & $\mathrm{B}$ & $\mathrm{B}$ & $\mathrm{B}$ \\
\hline 3 & ELBUDOWA & $\mathrm{B}$ & $\mathrm{B}$ & $\mathrm{B}$ & $\mathrm{B}$ & $\mathrm{B}$ & $\mathrm{B}$ & $\mathrm{B}$ & $\mathrm{B}$ & $\mathrm{C}$ \\
\hline 4 & $\mathrm{ELKOP}$ & $\mathrm{B}$ & $\mathrm{B}$ & $\mathrm{B}$ & $\mathrm{B}$ & $\mathrm{B}$ & $\mathrm{B}$ & $\mathrm{B}$ & $\mathrm{B}$ & $\mathrm{B}$ \\
\hline 5 & $\mathrm{ENAP}$ & $\mathrm{B}$ & $\mathrm{B}$ & $\mathrm{B}$ & $\mathrm{B}$ & $\mathrm{B}$ & $\mathrm{B}$ & $\mathrm{C}$ & $\mathrm{C}$ & $\mathrm{B}$ \\
\hline 6 & ERBUD & $\mathrm{B}$ & $\mathrm{B}$ & $\mathrm{B}$ & $\mathrm{B}$ & $\mathrm{B}$ & $\mathrm{B}$ & $\mathrm{B}$ & $\mathrm{C}$ & $\mathrm{C}$ \\
\hline 7 & ES-SYSTEM & $\mathrm{B}$ & $\mathrm{B}$ & $\mathrm{C}$ & $\mathrm{C}$ & $\mathrm{C}$ & $\mathrm{C}$ & $\mathrm{C}$ & $\mathrm{C}$ & $\mathrm{C}$ \\
\hline 8 & $\mathrm{FERRO}$ & $\mathrm{B}$ & $\mathrm{B}$ & $\mathrm{B}$ & $\mathrm{B}$ & $\mathrm{B}$ & $\mathrm{B}$ & $\mathrm{B}$ & $\mathrm{B}$ & $\mathrm{B}$ \\
\hline 9 & HERKULES & $\mathrm{C}$ & $\mathrm{C}$ & $\mathrm{C}$ & $\mathrm{C}$ & $\mathrm{C}$ & $\mathrm{C}$ & $\mathrm{C}$ & $\mathrm{C}$ & $\mathrm{C}$ \\
\hline 10 & INSTALKRK & $\mathrm{B}$ & $\mathrm{B}$ & $\mathrm{B}$ & $\mathrm{C}$ & $\mathrm{C}$ & $\mathrm{C}$ & $\mathrm{C}$ & $\mathrm{C}$ & $\mathrm{C}$ \\
\hline 11 & LENTEX & $\mathrm{B}$ & $\mathrm{B}$ & $\mathrm{B}$ & $\mathrm{B}$ & $\mathrm{C}$ & $\mathrm{C}$ & $\mathrm{C}$ & $\mathrm{C}$ & $\mathrm{C}$ \\
\hline 12 & MOSTALPLC & $\mathrm{B}$ & $\mathrm{B}$ & $\mathrm{B}$ & $\mathrm{B}$ & $\mathrm{B}$ & $\mathrm{B}$ & $\mathrm{C}$ & $\mathrm{C}$ & $\mathrm{B}$ \\
\hline 13 & MOSTALWAR & $\mathrm{B}$ & $\mathrm{B}$ & $\mathrm{B}$ & $\mathrm{B}$ & $\mathrm{C}$ & $\mathrm{C}$ & $\mathrm{C}$ & $\mathrm{C}$ & $\mathrm{C}$ \\
\hline 14 & MOSTALZAB & $\mathrm{B}$ & $\mathrm{C}$ & $\mathrm{C}$ & $\mathrm{B}$ & $\mathrm{B}$ & $\mathrm{C}$ & $\mathrm{C}$ & $\mathrm{C}$ & $\mathrm{C}$ \\
\hline 15 & PBGG & $\mathrm{B}$ & $\mathrm{B}$ & $\mathrm{B}$ & $\mathrm{B}$ & $\mathrm{C}$ & $\mathrm{C}$ & $\mathrm{C}$ & $\mathrm{C}$ & $\mathrm{C}$ \\
\hline 16 & PEMUG & $\mathrm{B}$ & $\mathrm{B}$ & $\mathrm{B}$ & $\mathrm{B}$ & $\mathrm{B}$ & $\mathrm{B}$ & $\mathrm{B}$ & $\mathrm{B}$ & $\mathrm{B}$ \\
\hline 17 & POLIMEXMS & $\mathrm{C}$ & $\mathrm{C}$ & $\mathrm{C}$ & $\mathrm{B}$ & $\mathrm{B}$ & $\mathrm{C}$ & $\mathrm{C}$ & $\mathrm{C}$ & $\mathrm{C}$ \\
\hline 18 & PROCHEM & $\mathrm{B}$ & $\mathrm{B}$ & $\mathrm{B}$ & $\mathrm{B}$ & $\mathrm{C}$ & $\mathrm{C}$ & $\mathrm{C}$ & $\mathrm{C}$ & $\mathrm{C}$ \\
\hline 19 & PROJPRZEM & $\mathrm{B}$ & $\mathrm{B}$ & $\mathrm{B}$ & $\mathrm{B}$ & $\mathrm{C}$ & $\mathrm{C}$ & $\mathrm{C}$ & $\mathrm{C}$ & $\mathrm{C}$ \\
\hline 20 & SELENA & $\mathrm{B}$ & $\mathrm{B}$ & $\mathrm{B}$ & $\mathrm{B}$ & $\mathrm{C}$ & $\mathrm{C}$ & $\mathrm{B}$ & $\mathrm{B}$ & $\mathrm{B}$ \\
\hline 21 & ULMA & $\mathrm{B}$ & $\mathrm{B}$ & $\mathrm{B}$ & $\mathrm{C}$ & $\mathrm{C}$ & $\mathrm{C}$ & $\mathrm{C}$ & $\mathrm{C}$ & $\mathrm{C}$ \\
\hline
\end{tabular}

Source: developed by the author.

Table 4. Overview of the degree of market-oriented development realized in electromechanical sector companies during years of 2010-2018

\begin{tabular}{|c|c|c|c|c|c|c|c|c|c|c|}
\hline No. & Company & $\mathbf{2 0 1 0}$ & $\mathbf{2 0 1 1}$ & $\mathbf{2 0 1 2}$ & $\mathbf{2 0 1 3}$ & $\mathbf{2 0 1 4}$ & $\mathbf{2 0 1 5}$ & $\mathbf{2 0 1 6}$ & $\mathbf{2 0 1 7}$ & $\mathbf{2 0 1 8}$ \\
\hline 1 & AMICA & $\mathrm{C}$ & $\mathrm{C}$ & $\mathrm{C}$ & $\mathrm{C}$ & $\mathrm{C}$ & $\mathrm{C}$ & $\mathrm{C}$ & $\mathrm{C}$ & $\mathrm{C}$ \\
\hline 2 & APATOR & $\mathrm{C}$ & $\mathrm{C}$ & $\mathrm{C}$ & $\mathrm{C}$ & $\mathrm{C}$ & $\mathrm{C}$ & $\mathrm{C}$ & $\mathrm{D}$ & $\mathrm{D}$ \\
\hline 3 & HYDROTOR & $\mathrm{C}$ & $\mathrm{C}$ & $\mathrm{C}$ & $\mathrm{C}$ & $\mathrm{C}$ & $\mathrm{C}$ & $\mathrm{C}$ & $\mathrm{C}$ & $\mathrm{C}$ \\
\hline 4 & INTROL & $\mathrm{B}$ & $\mathrm{B}$ & $\mathrm{C}$ & $\mathrm{C}$ & $\mathrm{C}$ & $\mathrm{C}$ & $\mathrm{C}$ & $\mathrm{C}$ & $\mathrm{C}$ \\
\hline 5 & LENA & $\mathrm{D}$ & $\mathrm{D}$ & $\mathrm{D}$ & $\mathrm{D}$ & $\mathrm{D}$ & $\mathrm{D}$ & $\mathrm{D}$ & $\mathrm{D}$ & $\mathrm{D}$ \\
\hline 6 & MANGATA & $\mathrm{C}$ & $\mathrm{C}$ & $\mathrm{C}$ & $\mathrm{C}$ & $\mathrm{C}$ & $\mathrm{D}$ & $\mathrm{D}$ & $\mathrm{D}$ & $\mathrm{D}$ \\
\hline 7 & PATENTUS & $\mathrm{C}$ & $\mathrm{C}$ & $\mathrm{C}$ & $\mathrm{C}$ & $\mathrm{C}$ & $\mathrm{C}$ & $\mathrm{C}$ & $\mathrm{C}$ & $\mathrm{C}$ \\
\hline 8 & RAFAKO & $\mathrm{D}$ & $\mathrm{D}$ & $\mathrm{D}$ & $\mathrm{D}$ & $\mathrm{D}$ & $\mathrm{D}$ & $\mathrm{D}$ & $\mathrm{D}$ & $\mathrm{D}$ \\
\hline 9 & RELPOL & $\mathrm{D}$ & $\mathrm{D}$ & $\mathrm{D}$ & $\mathrm{D}$ & $\mathrm{D}$ & $\mathrm{D}$ & $\mathrm{D}$ & $\mathrm{D}$ & $\mathrm{D}$ \\
\hline 10 & REMAK & $\mathrm{C}$ & $\mathrm{C}$ & $\mathrm{C}$ & $\mathrm{C}$ & $\mathrm{C}$ & $\mathrm{C}$ & $\mathrm{C}$ & $\mathrm{C}$ & $\mathrm{C}$ \\
\hline 11 & WIELTON & $\mathrm{C}$ & $\mathrm{C}$ & $\mathrm{C}$ & $\mathrm{C}$ & $\mathrm{C}$ & $\mathrm{C}$ & $\mathrm{C}$ & $\mathrm{C}$ & $\mathrm{C}$ \\
\hline 12 & ZPUE & $\mathrm{C}$ & $\mathrm{C}$ & $\mathrm{C}$ & $\mathrm{C}$ & $\mathrm{C}$ & $\mathrm{C}$ & $\mathrm{C}$ & $\mathrm{C}$ & $\mathrm{C}$ \\
\hline
\end{tabular}

Source: developed by the author.

It should be observed that as many as five companies had a global reach out of all of the analysed companies of the electromechanical sector in 2018 (APATOR, LENA, MANGATA, RAFAKO, and 
RELPOL); that is, they conducted their activity in more than 20 countries of the world. Due to this fact, the companies are rarely able to be characterized by further high dynamics of the growth of marketoriented development. The data presented in Table 5 shows that the IT sector companies are usually characterized by low dynamics of the growth of market-oriented development with a simultaneous small reach of this market. In 2018, seven out of the ten companies in the sector had a national reach, and the others had an international reach; there is no global enterprise among the companies of the sector.

Table 5. Overview of the degree of market-oriented development realized in IT sector companies during years of $2010-2018$

\begin{tabular}{|c|c|c|c|c|c|c|c|c|c|c|}
\hline No. & Company & $\mathbf{2 0 1 0}$ & $\mathbf{2 0 1 1}$ & $\mathbf{2 0 1 2}$ & $\mathbf{2 0 1 3}$ & $\mathbf{2 0 1 4}$ & $\mathbf{2 0 1 5}$ & $\mathbf{2 0 1 6}$ & $\mathbf{2 0 1 7}$ & $\mathbf{2 0 1 8}$ \\
\hline 1 & $\mathrm{ASSECOPOL}$ & $\mathrm{B}$ & $\mathrm{B}$ & $\mathrm{B}$ & $\mathrm{B}$ & $\mathrm{B}$ & $\mathrm{B}$ & $\mathrm{B}$ & $\mathrm{B}$ & $\mathrm{B}$ \\
\hline 2 & $\mathrm{COMARCH}$ & $\mathrm{B}$ & $\mathrm{B}$ & $\mathrm{C}$ & $\mathrm{C}$ & $\mathrm{C}$ & $\mathrm{C}$ & $\mathrm{C}$ & $\mathrm{C}$ & $\mathrm{C}$ \\
\hline 3 & $\mathrm{ELZAB}$ & $\mathrm{B}$ & $\mathrm{B}$ & $\mathrm{B}$ & $\mathrm{B}$ & $\mathrm{C}$ & $\mathrm{C}$ & $\mathrm{C}$ & $\mathrm{B}$ & $\mathrm{B}$ \\
\hline 4 & $\mathrm{IFIRMA}$ & $\mathrm{B}$ & $\mathrm{B}$ & $\mathrm{B}$ & $\mathrm{B}$ & $\mathrm{B}$ & $\mathrm{B}$ & $\mathrm{B}$ & $\mathrm{B}$ & $\mathrm{B}$ \\
\hline 5 & OPTEAM & $\mathrm{B}$ & $\mathrm{B}$ & $\mathrm{B}$ & $\mathrm{B}$ & $\mathrm{B}$ & $\mathrm{B}$ & $\mathrm{B}$ & $\mathrm{B}$ & $\mathrm{C}$ \\
\hline 6 & PROCAD & $\mathrm{B}$ & $\mathrm{B}$ & $\mathrm{B}$ & $\mathrm{B}$ & $\mathrm{C}$ & $\mathrm{C}$ & $\mathrm{B}$ & $\mathrm{C}$ & $\mathrm{C}$ \\
\hline 7 & SIMPLE & $\mathrm{B}$ & $\mathrm{B}$ & $\mathrm{B}$ & $\mathrm{B}$ & $\mathrm{B}$ & $\mathrm{B}$ & $\mathrm{B}$ & $\mathrm{B}$ & $\mathrm{B}$ \\
\hline 8 & SYGNITY & $\mathrm{B}$ & $\mathrm{B}$ & $\mathrm{B}$ & $\mathrm{B}$ & $\mathrm{B}$ & $\mathrm{B}$ & $\mathrm{B}$ & $\mathrm{B}$ & $\mathrm{B}$ \\
\hline 9 & TALEX & $\mathrm{B}$ & $\mathrm{B}$ & $\mathrm{B}$ & $\mathrm{B}$ & $\mathrm{B}$ & $\mathrm{B}$ & $\mathrm{B}$ & $\mathrm{B}$ & $\mathrm{B}$ \\
\hline 10 & WASKO & $\mathrm{B}$ & $\mathrm{B}$ & $\mathrm{B}$ & $\mathrm{B}$ & $\mathrm{B}$ & $\mathrm{B}$ & $\mathrm{B}$ & $\mathrm{B}$ & $\mathrm{B}$ \\
\hline
\end{tabular}

Source: developed by the author.

At the same time, the research revealed that two companies (COMARCH and OPTEAM) extended their geographical markets during the years of 2010-2018, yet some of the companies did not mark significant changes in this scope (ASSECOPOL, IFIRMA, SIMPLE, SYGNITY, TALEX, nor WASKO). The remaining two companies (ELZAB and PROCAD) were characterized with a periodical extension and limitation of their markets of activity. What results from the data presented in Table 6 is that the metallurgical sector is a sector with high dynamics of changes within the scope of market-oriented development.

Table 6. Overview of the degree of market-oriented development realized in metallurgical sector companies during years of 2010-2018

\begin{tabular}{|c|c|c|c|c|c|c|c|c|c|c|}
\hline No. & Company & $\mathbf{2 0 1 0}$ & $\mathbf{2 0 1 1}$ & $\mathbf{2 0 1 2}$ & $\mathbf{2 0 1 3}$ & $\mathbf{2 0 1 4}$ & $\mathbf{2 0 1 5}$ & $\mathbf{2 0 1 6}$ & $\mathbf{2 0 1 7}$ & $\mathbf{2 0 1 8}$ \\
\hline 1 & ALCHEMIA & $\mathrm{C}$ & $\mathrm{C}$ & $\mathrm{C}$ & $\mathrm{C}$ & $\mathrm{D}$ & $\mathrm{D}$ & $\mathrm{D}$ & $\mathrm{D}$ & $\mathrm{D}$ \\
\hline 2 & BORYSZEW & $\mathrm{B}$ & $\mathrm{B}$ & $\mathrm{B}$ & $\mathrm{C}$ & $\mathrm{C}$ & $\mathrm{C}$ & $\mathrm{C}$ & $\mathrm{C}$ & $\mathrm{C}$ \\
\hline 3 & COGNOR & $\mathrm{C}$ & $\mathrm{C}$ & $\mathrm{C}$ & $\mathrm{C}$ & $\mathrm{C}$ & $\mathrm{C}$ & $\mathrm{C}$ & $\mathrm{C}$ & $\mathrm{C}$ \\
\hline 4 & FASING & $\mathrm{B}$ & $\mathrm{C}$ & $\mathrm{C}$ & $\mathrm{C}$ & $\mathrm{D}$ & $\mathrm{D}$ & $\mathrm{D}$ & $\mathrm{D}$ & $\mathrm{D}$ \\
\hline 5 & FERRUM & $\mathrm{C}$ & $\mathrm{C}$ & $\mathrm{C}$ & $\mathrm{C}$ & $\mathrm{C}$ & $\mathrm{C}$ & $\mathrm{C}$ & $\mathrm{C}$ & $\mathrm{C}$ \\
\hline 6 & HUTMEN & $\mathrm{C}$ & $\mathrm{C}$ & $\mathrm{C}$ & $\mathrm{C}$ & $\mathrm{D}$ & $\mathrm{D}$ & $\mathrm{D}$ & $\mathrm{D}$ & $\mathrm{D}$ \\
\hline 7 & IMPEXMET & $\mathrm{D}$ & $\mathrm{D}$ & $\mathrm{D}$ & $\mathrm{D}$ & $\mathrm{D}$ & $\mathrm{D}$ & $\mathrm{D}$ & $\mathrm{D}$ & $\mathrm{D}$ \\
\hline 8 & KETY & $\mathrm{C}$ & $\mathrm{C}$ & $\mathrm{C}$ & $\mathrm{D}$ & $\mathrm{D}$ & $\mathrm{D}$ & $\mathrm{D}$ & $\mathrm{D}$ & $\mathrm{D}$ \\
\hline 9 & KGHM & $\mathrm{C}$ & $\mathrm{C}$ & $\mathrm{C}$ & $\mathrm{C}$ & $\mathrm{C}$ & $\mathrm{D}$ & $\mathrm{D}$ & $\mathrm{D}$ & $\mathrm{D}$ \\
\hline 10 & MENNICA & $\mathrm{B}$ & $\mathrm{B}$ & $\mathrm{B}$ & $\mathrm{C}$ & $\mathrm{C}$ & $\mathrm{C}$ & $\mathrm{C}$ & $\mathrm{C}$ & $\mathrm{C}$ \\
\hline 11 & ODLEWNIE & $\mathrm{B}$ & $\mathrm{B}$ & $\mathrm{C}$ & $\mathrm{C}$ & $\mathrm{C}$ & $\mathrm{C}$ & $\mathrm{C}$ & $\mathrm{C}$ & $\mathrm{C}$ \\
\hline 12 & PERMEDIA & $\mathrm{C}$ & $\mathrm{C}$ & $\mathrm{C}$ & $\mathrm{C}$ & $\mathrm{C}$ & $\mathrm{C}$ & $\mathrm{C}$ & $\mathrm{C}$ & $\mathrm{C}$ \\
\hline 13 & STALPROD & $\mathrm{C}$ & $\mathrm{C}$ & $\mathrm{D}$ & $\mathrm{D}$ & $\mathrm{D}$ & $\mathrm{D}$ & $\mathrm{D}$ & $\mathrm{D}$ & $\mathrm{D}$ \\
\hline
\end{tabular}

Source: developed by the author. 
In 2018, 7 of the 13 companies were characterized with a global reach, whereas the others had an international reach. At the same time, nine companies (ALCHEMIA, BORYSZEW, FASING, HUTMEN, KETY, KGHM, MENNICA, ODLEWNIE, and STALPROD) extended their geographical markets of activity during the analysed period, and the others (COGNOR, FERRUM, IMPEXMET, and PGO) did not mark any changes within this scope. In the metallurgical sector, there were no companies which permanently or temporarily limited their markets of activity. On the basis of the research findings presented in Table 7, we can see that the food sector is a stable sector in view of the analysed issue. In 2018, five companies of this sector had a global reach, and the remaining five companies - an international reach.

Table 7. Overview of the degree of market-oriented development realized in food sector companies during years of 2010-2018

\begin{tabular}{|c|c|c|c|c|c|c|c|c|c|c|}
\hline No. & Company & $\mathbf{2 0 1 0}$ & $\mathbf{2 0 1 1}$ & $\mathbf{2 0 1 2}$ & $\mathbf{2 0 1 3}$ & $\mathbf{2 0 1 4}$ & $\mathbf{2 0 1 5}$ & $\mathbf{2 0 1 6}$ & $\mathbf{2 0 1 7}$ & $\mathbf{2 0 1 8}$ \\
\hline 1 & AMBRA & B & B & B & C & C & C & C & D & D \\
\hline 2 & GOBARTO & D & D & D & D & D & D & D & D & D \\
\hline 3 & INDYKPOL & C & C & C & C & C & C & D & D & D \\
\hline 4 & KERNEL & C & C & C & C & C & C & C & C & C \\
\hline 5 & KSGAGRO & C & C & C & C & C & C & C & C & C \\
\hline 6 & KRUSZWICA & B & B & B & B & B & B & C & C & C \\
\hline 7 & MILKILAND & D & D & D & D & D & D & D & D & D \\
\hline 8 & PEPEES & B & B & B & B & B & C & C & C & C \\
\hline 9 & WAWEL & D & D & D & D & D & D & D & D & D \\
\hline 10 & ZYWIEC & C & C & C & C & C & C & C & C & C \\
\hline
\end{tabular}

Source: developed by the author.

AMBRA, INDYKPOL, KRUSZWICA, and PEPEES, are companies that extended their geographical markets of activity during the studied period, whereas GOBARTO, KERNEL, KSGAGRO, MILKILAND, WAWEL, and ŻYWIEC marked no significant changes within that scope. Companies limiting their market did not occur - neither periodically or permanently.

Conclusion. Tables 8-11 and Figure 2 list all of the studied companies from the point of view of the scopes of changes in their geographical markets of activity, adopting the direction of changes marked during the research as a criterion of the division. The presentation included in Table 8 lists the totality of the companies of all of the studied sectors that extended their geographical markets of activity during the years of 2010-2018. This suggests that they all realized pro-market business models during the subjective period. The fact also shows that the presented companies realized the strategy of market diversification at that time.

During the various years of the analysed period, the companies listed in Table 9 were characterized by both the extension and limitation of their geographical markets of activity. Among them, only companies from two of the studied sectors are represented (IT and construction). The economic practice indicates that this fact could be influenced by changes in the market situation that had a significant impact on the two sectors. In this situation, a withdrawal from the market takes place during periods of the economic slump, and in the case of a good economic situation - entrance to the market.

Table 10 shows that there were companies that did not introduce significant changes within their markets of activity in each of the studied sectors. This proves that these enterprises did not implement pro-market business models during the analysed period. 
Table 8. List of enterprises extending their geographical markets of activity during years of 2010-2018

\begin{tabular}{|c|c|c|c|c|c|}
\hline No. & Company & Sector & No. & Company & Sector \\
\hline 1 & BUDIMEX & Construction & 16 & COMARCH & IT \\
\hline 2 & DECORA & Construction & 17 & OPTEAM & IT \\
\hline 3 & ELBUDOWA & Construction & 18 & ALCHEMIA & Metallurgical \\
\hline 4 & ERBUD & Construction & 19 & BORYSZEW & Metallurgical \\
\hline 5 & ES-SYSTEM & Construction & 20 & FASING & Metallurgical \\
\hline 6 & INSTALKRK & Construction & 21 & HUTMEN & Metallurgical \\
\hline 7 & LENTEX & Construction & 22 & KETY & Metallurgical \\
\hline 8 & MOSTALWAR & Construction & 23 & KGHM & Metallurgical \\
\hline 9 & PBG & Construction & 24 & MENNICA & Metallurgical \\
\hline 10 & PROCHEM & Construction & 25 & ODLEWNIE & Food \\
\hline 11 & PROJPRZEM & Construction & 26 & STALPROD & Food \\
\hline 12 & ULMA & Construction & 27 & AMBRA & Food \\
\hline 13 & APATOR & Electromechanical & 28 & INDYKPOL & Food \\
\hline 14 & INTROL & Electromechanical & 29 & KRUSZWICA & PEPEES \\
\hline 15 & MANGATA & Electromechanical & 30 & & \\
\hline
\end{tabular}

Source: developed by the author.

Table 9. List of enterprises extending and limiting the geographical market of activity during years of 2010-2018

\begin{tabular}{|c|c|c|}
\hline No. & Company & Sector \\
\hline 1 & ENAP & Construction \\
\hline 2 & MOSTALPLC & Construction \\
\hline 3 & MOSTALZAB & Construction \\
\hline 4 & POLIMEXMS & Construction \\
\hline 5 & SELENA & Construction \\
\hline 6 & ELZAB & IT \\
\hline 7 & PROCAD & IT \\
\hline
\end{tabular}

Source: developed by the author.

Table 10. List of enterprises characterized by lack of significant changes in the geographical market of activity during years of 2010-2018

\begin{tabular}{|c|c|c|}
\hline No. & Company & Sector \\
\hline 1 & $\mathbf{2}$ & $\mathbf{3}$ \\
\hline 1 & ELKOP & Construction \\
\hline 2 & FERRO & Construction \\
\hline 3 & HERKULES & Construction \\
\hline 4 & PEMUG & Construction \\
\hline 5 & AMICA & Electromechanical \\
\hline 6 & HYDROTOR & Electromechanical \\
\hline 7 & LENA & Electromechanical \\
\hline 8 & PATENTUS & Electromechanical \\
\hline 9 & RAFAKO & Electromechanical \\
\hline 10 & RELPOL & Electromechanical \\
\hline 11 & REMAK & Electromechanical \\
\hline 12 & WIELTON & Electromechanical \\
\hline 13 & ZPUE & IT \\
\hline 14 & ASSECOPOL & \\
\hline
\end{tabular}




\begin{tabular}{|c|c|c|}
\hline \multicolumn{2}{|c|}{ Continue Table 10 } \\
\hline 1 & $\mathbf{2}$ & $\mathbf{3}$ \\
\hline 15 & IBSYSTEM & IT \\
\hline 16 & SIMPLE & IT \\
\hline 17 & SYGNITY & IT \\
\hline 18 & TALEX & IT \\
\hline 19 & WASKO & Metallurgical \\
\hline 20 & COGNOR & Metallurgical \\
\hline 21 & FERRUM & Metallurgical \\
\hline 22 & IMPEXMET & Food \\
\hline 23 & PGO & Food \\
\hline 24 & GOBARTO & Food \\
\hline 25 & KERNEL & Food \\
\hline 26 & KSGAGRO & Food \\
\hline 27 & MILKILAND & Food \\
\hline 28 & WAWEL & \\
\hline 29 & ZYWIEC & \\
\hline
\end{tabular}

Source: developed by the author.

What results from the data included in Table 11 and in Figure 2 is that the majority of the analysed enterprises (30 companies - 45\%) extended their geographical markets of activity during the analysed period, almost the same number of the total number of enterprises (namely, 29 companies - 44\%) did not mark any significant changes within this scope, whereas $11 \%$ of the enterprises (that is, 7 companies) made both extensions and limitations of their geographical markets of activity during the same period.

Table 11. Changes in the geographical market of enterprise activity during years of 2010-2018

\begin{tabular}{|l|c|c|}
\hline \multicolumn{1}{|c|}{ Categories of change } & $\begin{array}{c}\text { Number of } \\
\text { enterprises }\end{array}$ & $\begin{array}{c}\text { Percentage of } \\
\text { enterprises }\end{array}$ \\
\hline Extension of market & 30 & 45 \\
\hline Limitation of market & 0 & 0 \\
\hline Extension and limitation of market & 7 & 11 \\
\hline $\begin{array}{l}\text { No significant changes within the scope of extension and limitation of } \\
\text { market }\end{array}$ & 29 & 44 \\
\hline
\end{tabular}

Source: developed by the author.

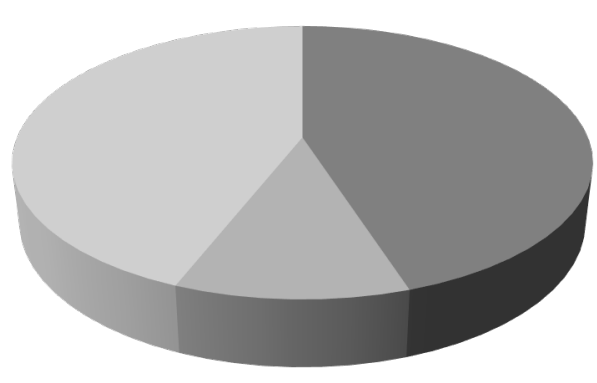

Extension of the market (30 entities)

Limitation of the market ( 0 entities)

Extension and limitation of the market (7 entities)

No significant changes within the scope of extension and limitation of the market ( 29 entities)

Figure 2. Changes in the geographical market of enterprise activity during years of $\mathbf{2 0 1 0 - 2 0 1 8 ~ ( \% ) ~}$ Source: developed by the author. 
It should also be observed that there was none that would be characterized only with the limitation of their geographical market of activity among all of the studied companies.

The data show that less than half of all of the enterprises implemented pro-market business models; at the same time, nearly the same number of companies were not interested in this model. The remaining percentage of the enterprises implemented pro-market business model concepts only periodically.

Funding. The article has been financed with subsidies granted to the Project financed by the Ministry of Science and Higher Education within «Regional Initiative of Excellence» Programme for 2019-2022. Project no.: 021/RID/2018/19. Total financing: 11897 131,40 PLN

\section{References}

Abdelkafi, N., Tauscher, K., 2016, Business models for sustainability from a system dynamics perspective, Organization and Environment, No. 29, pp. 74-96. https://doi.org/10.1177/1086026615592930.

Afuah, A.N, Tucci, Ch.L., 2003, Internet Business Models and Strategies: Text and Cases, McGraw Hill, New York, p. 20.

Ansoff, H.I., 1965, Corporate Strategy. An Analytic Approach to Business Policy for Growth and Expansion, McGraw-Hill Book

Co., New York, p. 109.

Ansoff, H.I., 1957, Strategies for diversification, Harvard Business Review, No. 35, pp. 113-124. https://doi.org/10.1016/00246301(72)90048-9.

Arend, R., 2013, The business model: Present and future - beyond a skeumorph, Strategic Organisation, Vol. 11(4), pp. 390402

Baden-Fuller, Ch., Mangematin, V., 2013, Business models: A challenging agenda, Strategic Organisation, Vol. 11(4), pp. 418-427.

Boyd, H.W., Walker, O.C., Larréché, J.C., 1995, Marketing Management. A Strategic Approach with a Global Orientation Irwin, Chicago, p. 35.

Buckley, P.J., Tian, X., 2017, Internalization theory and the performance of emerging-market multinational enterprises, International Business Review, No. 26, pp. 976-990.

Casadesus-Masanell, R., Ricart, J.E., 2010, From strategy to business models and onto tactics, Long Range Planning, Vol. 43, no. 2-3, pp. 195-215.

Chesbrough, H., Rosenbloom, R.S., 2002, The Role of the Business Model In Capturing Value from Innovation: Evidence from Xerox Corporation's Technology Spinn-off Companies, Industrial and Corporate Change, Vol. 11, no. 3, p. 534.

Creswell, J.W., 2014, Research design, Internatio. Los Angeles, London, New Delhi, Singapore, Washington, DC: Sage.

Cygler, J., Wyka, 2019, Internal barriers to international R\&D cooperation: the case of Polish high tech firms, Forum Scientiae

Oeconomia, Vol. 7, No. 1, p. 25-26.

DaSilva, C.M., Trkman, P., 2014, Business model: What is it and what it is not?, Long Range Planning, No. 47, pp. $227-246$.

Doligalski, T., 2018, Internet Business Models and Types of Goods Offered (November 9, 2018), Journal of Business Models,

Vol. 6, No. 2, pp. 32-36, 2018. Available at SSRN: https://ssrn.com/abstract=3281756.

Geissdoerfer, M., Vladimirova, D., Evans, S., 2018, Sustainable Business Model Innovation: A Review, Journal of Cleaner

Production, No. 198, pp. 401-416.

Grassl, W., 2012, Business Models of Social Enterprise: A Design Approach to Hybridity, ACRN Journal of Entrepreneurship Perspectives, Vol. 1, Issue 1, pp. 37-60, ISSN 2224-9729.

Havemo, E., 2018, A visual perspective on value creation: Exploring patterns in business model diagrams, European Management Journal, Vol. 36, Iss. 4, pp. 441-452.

Holopainen, M., Toivonen, M., 2012, Weak signals: Ansoff today, Futures, Vol. 44, Iss. 3, pp. 198-205.

Johne, A., Storey, C., 1998, New service development: a review of the literature and annotated bibliography, Eur. J. Mark.

Manag., vol. 32, No. 3/4, pp. 184-251. 52.

Johnson, M., Christensen, C., Kagermann, H., 2008, Reinventing Your Business Model, Harvard Business Review, Vol. 86, p.

Magretta, J., 2002, Why business models matter, Harvard Business Review, Vol. 80, pp. 86-92.

Osterwalder, A., Pigneur, Y., Tucci, C.L., 2005, Clarifying Business Models: Origin, Present and Future of the Concept, Communications of the Association for Information Systems, Vol. 15, pp. 1-40.

Osterwalder, A., Pigneur, Y., 2010, Business Model Generation: A Handbook for Visionaries, Game Changers, and Challengers, John Wiley \& Sons, Inc., New Jersey.

Pelikanowa, R., McGregor, R., 2019, The impact of the new EU trademark regime on entrepreneurial competitiveness, Forum Scientiae Oeconomia, Vol. 7, No. 2, p. 53-54. 
Richardson, J., 2008, The business model: an integrative framework for strategy execution, Strategic Change, Vol. 17, no. 56, pp. 133-144.

Shafer, S., Smith, H., Linder, J., 2005, The Power of Business Models, Business Horizons, Vol. 48, Iss. 3, pp. 199-207.

Smith, W., Binns, A., Tushman, M., 2010, Complex Business Models: Managing Strategic Paradoxes Simultaneously, Long Range Planning, Vol. 43, p. 450.

Teece, D.J., 2010, Business model, business strategy and innovation, Long Range Planning, No. 43.

Thompson, A.A, Strickland, A.J., 2003, Strategic Management: Concepts and Cases, McGraw-Hill, New York, p. 3.

Zapletalova, B., 2017, Competitive strategies of the SMEs: empirical evidence from the Czech Republic, Forum Scientiae Oeconomia, Vol. 5, No. 3, p. 11-15

Zott, C., Amit, R., 2010, Business Model Design: An Activity System Perspective, Long Range Planning, Vol. 43, p. 222.

Zott, C., Amit, R., Massa, L., 2011, The Business Model: Recent Developments and Future Research, Journal of Management, Vol 37.

Томаш Роєк, Ph.D., Краківський економічний університет (Польща).

Аналіз проринкової концепції бізнес-моделі

Сучасні концепції бізнес-моделей переважно орієнтовані на досягнення максимального розвитку підприємств. При иьому розвиток підприємств прямо залежить від обсягів залучених ресурсів, підвищення конкурентоспроможності та продуктивності праці. Автором зазначено, що на формування бізнес-моделі підприємства впливають як зовнішні, так і внутрішні фактори. У свою чергу, під внутрішніми фракторами розуміють можливості зростання підприємства та ефективність управління ним. Зовнішні фактори формуються у ході співпраці підприємства з іншими суб'єктами господарювання та якості інституціонального середовища. Крім того, на формування бізнес-моделі підприємства впливають раніше прийняті стратегії розвитку. При цьому напрями розвитку підприємства виступають детермінантами і модифрікаторами у процесі прийняття рішень, а також вибору адекватної стратегії подальшого розвитку. Систематизація наукових напрацювань з означеної проблематики засвідчила, що товарно- та ринково-орієнтовані стратеаії розвитку є найбільш досліджуваними тематиками у даному напрямі. Базуючись на прикладах успішних підприємств, автором наголошено, що розвиток підприємств може бути досягнутий двома шляхами. Так, автором виділено дві концепції бізнес-моделей, а саме: протоварна та проринкова концепції. У рамках даної статmі висвітлено проблеми ринковоорієтованого розвитку підприємств, проринкової концепції бізнес-моделі, а також пов'язаних із ними стратегій розвитку. У свою чергу, емпіричне дослідження проведено на основі панельних даних, сфрормованих на основі даних обраної групи компаній, акції яких котируються на фондових біржах за 2010-2018 рр. Для аналізу панельних даних авторами використано аналіз частоти використання концепції бізнес-моделі. Таким чином, головна мета даної статті полягає у оцінці сучасних бізнес-моделей, спрямованих на розвиток підприємства та використовуваних стратегії розвитку. Відповідно до поставленої мети, автором перевірено гіпотезу: $\mathrm{H}$ - проринкова концепиія бізнес-моделі $є$ провідною концепцією серед підприємств Польщі. у теоретичній частині дослідження приведено огляд та критичний аналіз літературних джерел з досліджуваної тематики, в той час як емпірична частина містить стратегічний аналіз компаній (зокрема, модель Ансофра) на основі матричного вектору. При цьому дана модель трансформована та модифрікована у відповідності до головної мети дослідження. Застосування даної моделі дозволило автору визначити підприємства, які використовують аналізовану концепцію бізнес-моделі в групі досліджуваних підприємств та стратегій розвитку, які застосовуються цими підприємствами. Результати дослідження мають практичне значення і сприяють полегшеному процесу прийняття рішення польськими підприємиями при виборі правильної бізнес-моделі та передбаченні наслідків.

Ключові слова: розвиток бізнесу, бізнес-модель, стратегії розвитку, розвиток підприємства, проринкова концепція бізнес-моделі, стратегічний менеджмент.

Manuscript received: 26.03.2019.

(C) The author(s) 2019. This article is published with open access at Sumy State University. 